\title{
Impacts and preventative measures against flooding and coastal erosion in Thailand
}

\author{
S. Pongpiachan ${ }^{1}$, T. Settacharnwit ${ }^{1}$, P. Chalangsut ${ }^{1}$, \\ P. Hirunyatrakul ${ }^{2} \&$ I. Kittikoon ${ }^{2}$ \\ ${ }^{1}$ NIDA Centre for Research and Development on Disaster Prevention \\ and Management, School of Social and Environmental Development, \\ National Institute of Development Administration (NIDA), Thailand \\ ${ }^{2}$ Bara Scientific Co., Ltd., Bangkok, Thailand
}

\begin{abstract}
The purpose of this paper is to describe the natural disasters of flooding and coastal erosion in Thailand, which have resulted in many deaths and large-scale property damage. The magnitude and frequency of Thailand's flooding in the past and the present are also examined.

The MIKE 11 and URSB hydrological models are shown to be the most suitable models for forecasting floods in Thailand, as well as for planning short and long term protection and mitigation measures.

With its long length of coastline on both the Gulf of Thailand and the Andaman Sea, Thailand faces the increasing occurrence of coastal erosion. The major causes of coastal erosion originate from both natural processes and human activities. A simulation of a rise in sea level by incremental degrees and their potential impact on some major cities in Southeast Asia is described and measures to mitigate and limit the negative impact of coastal erosion are presented in order to preserve the environment for future generations.

Keywords: flooding, coastal erosion, Thailand, hydrological model, sea level rise, mitigate and adaptation limit.
\end{abstract}

\section{Introduction}

The threat of environmental problems has become an increasingly more pressing issue in Thailand, owing to the tremendous negative impact on human life and property. Thailand is subject to many natural disasters including floods, tropical 
cyclones, earthquakes, thunderstorms, landslides, storm surges, coastal erosion, sea level rises, fires and drought (TMD [1]). Meanwhile, human activities also deplete natural resources at an ever-growing rate. Deforestation and industrialization have led to changes in land use from agricultural to residential and commercial, which has also had a negative impact on the biodiversity in the region as pointed out by McDonald [2] and Chunkaew [3]. In many situations, the eco system has the ability to rehabilitate itself or show its resilience by bouncing back after an external disturbance that is not too drastic (Miller [4]). However, its vulnerability is exacerbated when combined with the destructive impact of human activities (IPCC [5]).

This paper aims to present the disasters of flooding and coastal erosion in Thailand, which have occurred more frequently and violently over the last decade. The flooding at the end of 2010 overwhelmed 51 provinces, leaving 258 dead and 8.97 million people affected (Nirapai Center [6] and CRED [7]). Likewise, 11 percent of the coastline along the Gulf of Thailand and two percent of the Andaman Sea coastline are eroding at a rate of more than five meters a year (or two square kilometers of coastal real estate). The damage has been estimated at approximately \$US 156 million/year (Jarungrattanapong and Manasboonphempool [8]). The causes of flooding and coastal erosion are examined and recommendations for short and long term prevention and mitigation measures are presented in this paper.

\section{Flooding}

Flooding is the single most destructive type of natural disaster that strikes humans and their livelihoods around the world. Agencies provide a variety of definitions of flooding, as follows: The United Nations, International Strategy for Disaster Reduction (UNISDR) explains that "flooding can arise from overflowing river, heavy rainfall over the short period or an unusual inflow of sea water onto land, such as storm surge, tidal flooding, seismic events (tsunami) or large landslide" (Pilon [9]).

The United States Environmental Protection Agency (USEPA) defines universally that "flood or flooding means a general and temporary condition of partial or complete inundation of normally dry land areas from the overflow of inland and/or tidal waters and/or the unusual and rapid accumulation or runoff of surface water from any source or flooding from any other source." Meanwhile, the European Union (EU) Directives define flooding as "the temporary covering by water of land not normally covered by water." This definition include floods from "rivers, mountain torrents, Mediterranean ephemeral water courses, and floods from the sea in coastal areas," but and may exclude floods from sewerage systems. The American Meteorological Society defines the meaning of flooding as the "overflowing of the normal confines of a stream or other body of water, or the accumulation of water over areas that are not normally submerged." These attempts illustrate the difficulty in arriving at a precise definition of "flood or flooding." 
In the case of Thailand, there are three types of flooding that can be characterized by pattern and severity as follows: 1) general or regular flooding, characterized by the unusual presence of water on normally dry lands. 2) flash flooding, which occurs with heavy rainfall over a short period of time, and 3) river flooding, used to describe overwhelmed or overflowing rivers (TMD [10]). However, Thailand is also confronted by the more rarely-occurring ocean flooding, defined by a sudden inflow of sea water onto land, such as the tsunami created by the earthquake in the Indian Ocean on December 26, 2004 which caused large-scale social and economic damage in Thailand (UNESCO [11]).

\subsection{Flooding and climate change}

Several models have been used to investigate the impact of climate change on the magnitude of flooding in different regions. For instance, the Nicholls model predicts the average annual people flooded (AAPF) based on three different scenarios - namely low-, middle-, and high sea-level rises - as a consequence of climate change [12]. Although major uncertainties were found in the model, the relatively strong tendency towards the increase of the AAPF as a result of sealevel rises is predominant. It is also worth mentioning that the incidence of flooding triggered by sea-level rises greatly depends on the geophysical conditions of individual regions.

In addition, the occurrence of flooding in West Africa, East Africa, the Southern Mediterranean, the Southeast Asia, and the South Asia will be intensified and worsen if there are no actions on reducing green house gases (mitigation) and developing of the coastal planning and management (adaptation) (Nicholls and Mimura [13]). In addition, sea level rises and flooding of coastal lands will lead to salination or contamination of fresh water and agricultural lands, and the loss of nursery areas for fishing (Costello et al. [14]). Since the intensity of river overflow is a function of water run-off volume and precipitation, it is therefore crucial to assess the influence of these two parameters on occurrences of river flooding (Kozka and Holko [15]). The impact of climate change on river flooding was estimated by combining the stochastic precipitation model with current climate change conditions (Booij [16]).

There are a number of hydrological basin models developed for flood forecasting, including TOPMODEL, HBV, MIKE 11, URBS and GCMs. The criteria for model selection are comprised of objectives/purposes of flood forecasting, required data for each model, and the conditions of topography characteristics, catchments, estuaries, run-off and rainfall volume. For example, UBC, the Canadian model used for forecasting run-off from mountain catchments, has the advantage of estimating depletion and operating entirely from meteorological inputs of daily maximum and minimum temperatures and precipitation. However, its disadvantage is the difficulty of collecting scarce meteorological and sparse stream data in mountain areas, if available, a more extensive database can be utilised. If the objective is to forecast global weather patterns, GCM should be considered, since it can operate under various conditions but has large biases. HBV is applied to various different climate conditions while MIKE 11 is used for multi-purpose forecasts. 
Some of the hydrological models have been applied to planning for the protection from and mitigation of flooding disasters in the Southeast Asia subregion.

The URBS model was applied for flood forecasting in LMB instead of existing forecasting models that are out of date and unreliable. Furthermore, users can make use of URBS' simple recovering initial loss rainfall runoff model or integrate the results from a third party water model (MRC [17], Malone [18] and Carroll [19]). In Thailand, the Danish hydrodynamic model, MIKE 11 is considered the most suitable model for forecasting and management of floods since it can be applied to many purposes.

The standard MIKE 11 model provides applications for long-term forecasting accuracy that include: 1) real-time monitoring and decision support 2) real-time flood forecasting and warning system 3) control of dams, reservoirs and hydraulic structures, and 4) water resource and environment monitoring (Skotner et al. [20]). Nevertheless, there are several disadvantages to MIKE 11 such as numerical instabilities when river segments run dry and water balance errors (Narrabri Shire Council [21]). The Water Crisis Prevention Center has utilized MIKE 11 for flood forecasting in the Chao Phraya River Basin and has employed this model to calibrate and verify the extent of the flood disaster which occurred in 2006 and 2007. MIKE 11 was used for flood forecasting in 2008 to compare the observed results with data from the study area and statistical values. The results were quite acceptable and very reliable, and the system was used again to simulate one-dimensional flow in the Nam Loei River together with the generation of a map of the flooding areas (Chitprom and Patsinghasaneel [22] and Taesombat et al. [23]).

\subsection{Thailand's flooding situation}

Thailand is located at $17^{\circ} 00^{\prime} \mathrm{N} 100^{\circ} 00^{\prime} \mathrm{E} / 17^{\circ} \mathrm{N} 100^{\circ} \mathrm{E}$. Its topography is characterized by fertile floodplains with a tropical monsoon climate in the central area, marginal uplands and mountains in the Northern and the Northeastern regions, and low lands with long mountainous outcrops between the Gulf of Thailand and the Andaman Sea. In the case of Thailand, floods have occurred frequently since the Sukhothai regime (1257-1420 A.D.). Some stone inscriptions record the occurrences of floods at that time caused by the very large floodplain area and the huge volume of water flowing from the mountains in the extreme North which was unable to discharge into the Chao Phraya river.

The major flooding of Bangkok in 1942 was recorded as having effects on the city's infrastructure lasting three months; the trams had to stop operation downtown and boats had to be used for commuting to work. The major causes of this flooding were: 1) Bangkok's location on the central, flat flood plain of the Chao Phraya river basin with a low elevation above sea level, as shown in fig. 1, and 2) having heavy continuous rainfall before dams had been built in the northern region; therefore, it was difficult to restrain the high magnitude of water discharged before it reached Bangkok.

Thailand experienced severe flooding from October to December 2010 (fig. 2). The flooding was caused by the early arrival of the La Niña phenomenon 


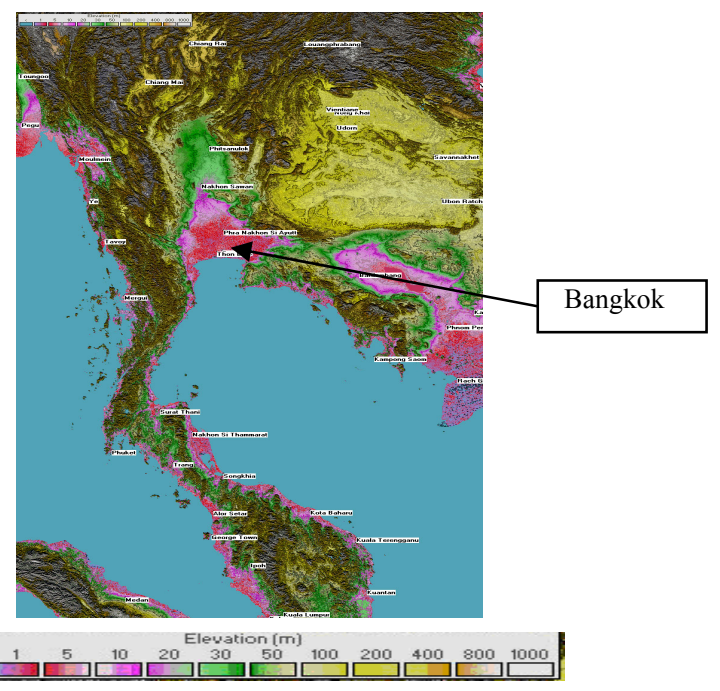

Figure 1: Map of elevation relative to sea level (m), Thailand (Source: www.globalwarmingart.com/wiki/Special:SeaLevel.)

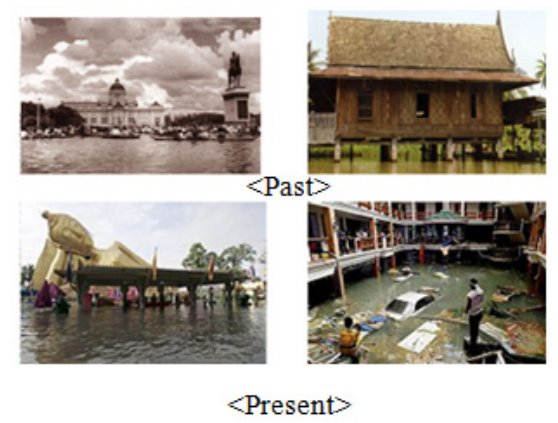

Figure 2: $\quad$ Flooding in the year 2010 compared with flooding in the past.

and heavy rain in many areas. It overwhelmed more than half the country's regions (51 of 76 provinces), leaving 258 people killed, and 8.97 million people affected. More than two million households and 3.2 million acres of farmland were affected; the rapid response flood inundation map is depicted in fig. 3 .

The highest frequency of flash flooding occurred in the Northern and the Southern areas, followed by general flooding and storm surge/coastal flooding in turn; however, the general flooding, flash flooding and storm surge/coastal flooding were also found, but less frequently, among the North Eastern, the Western and the Eastern regions (CRED [7]).

Since the northern part of Thailand has always experienced flash flooding, there is a wealth of appropriate local knowledge People know how to protect against floods and reduce water damage by building their houses in the 

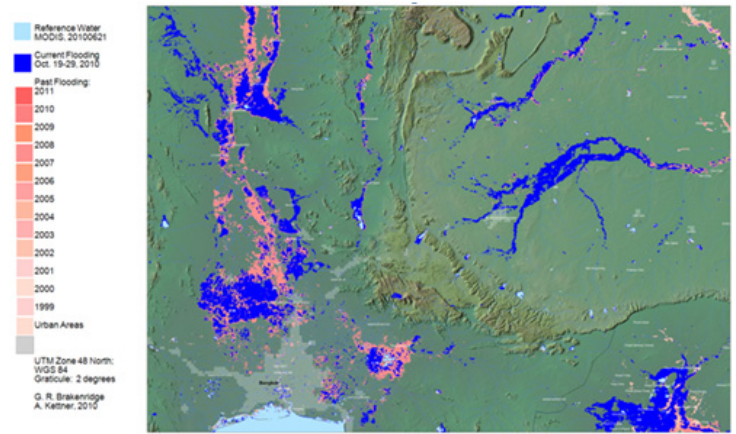

Figure 3: $\quad$ Rapid response flood inundation map, Thailand, October 10, 2010. (Source: www.floodobservatory.colorado.edu/hydrography/ E100N20 RR1.html_.)

traditional Thai style. The house has a high floor level allowing a man of average-height to walk with clearance above his head. The space under the house is used for storing farm equipment, keeping livestock, producing handicrafts, and as a common sitting or squatting area.

Due to the specific geophysical conditions of the Southern region, most areas used to be surrounded and covered by tropical rainforest. Furthermore, their tap roots and fibrous roots could capture soil at a deeper level to extend water retention time, protect against soil erosion and landslides. Nowadays, the rainforest areas have been reduced and substituted by rubber and palm oil plantations. The rubber tree tap roots have an average depth of no more than 1.52.0 meters (Wannasiri [24] and LDD [25]). Thus, when severe flash flooding occurred, most rubber trees were uprooted easily. Intrusion into mangrove forest areas by palm oil plantations, grown as an energy-producing crop has led to the reduction of these natural flooding buffer areas. Consequently, the combination of these events caused an extremely large amount of water from heavy rain to inundate the city and trigger landslides to lower areas.

The obvious example of this case is how the heavy rains from the tropical depression through the Gulf of Thailand brought serious flooding to Hat Yai, in Songkhla province, the main commercial district in the Southern part of Thailand in November, 2010, as shown in fig. 4.

To mitigate the catastrophic effects of flooding, all concerned parties should cooperate on setting short and long term plans and co-ordinate their action plans for flood management. In the short term, the planting of Vetiver grass in rubber plantations should be promoted, which can decelerate water velocity. The local authority should install early warning systems for floods and other natural disasters for protection and to enable people to be evacuated from risk areas in time. In the long run, to achieve more effective practical policies, the state policies on rainforest and mangrove reforestation for flood mitigation, coupled with city planning to relocate commercial zones to uphill areas to reduce property damage have to be implemented. 


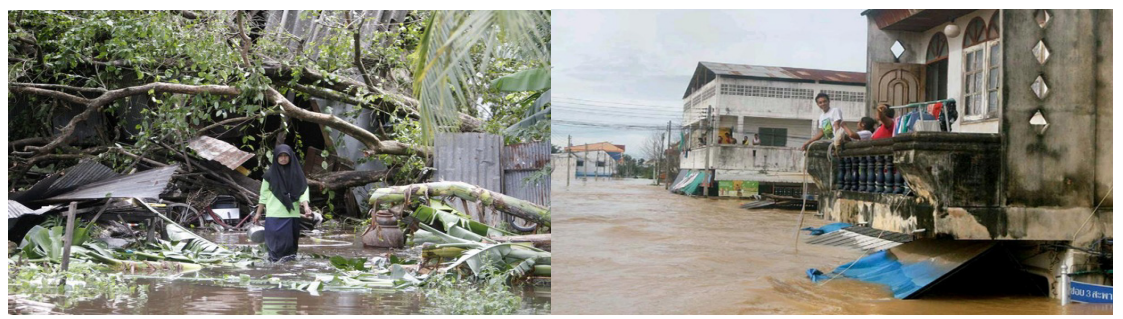

Figure 4: The damage of flooding in Hat Yai District, Thailand. November 2, 2010. (Source: www.reuters.com and www.bangkokpost.com.)

In the case of the city of Hat Yai, the government should consider adopting the URBS model which can be utilised to model a specific event or perform continuous simulations to help mitigate current conditions and events. Moreover, the conditions of the model are consistent with flood forecasting in the case of rare, high-rainfall events. Besides these advantages, URSB also allows users to configure the model to match the individual characteristics of catchment areas. The early warning system must be installed in parallel to reinforce the evacuation plan.

\section{Coastal erosion}

Coastal erosion is a major issue for countries that have coastlines, especially in most Pacific Islands; a solution to this problem needs to be found urgently or at least measures to alleviate the damage (South [26]). The UK's Department of Environment Food and Rural Affairs has defined coastal erosion as a natural process by which coastlines adjust to varying sea levels, energy levels, sediment supply and existing topography. Over most of the ten millennia of the Holocene Period (characterized by generally rising global sea levels), coastlines have undergone substantial erosion and deposition to gradually assume their current configuration. Some continue to evolve through large-scale redistribution of sediment through erosion and deposition. Management problems arise when fixed human infrastructure is threatened with destruction by coastal erosion" (Cooper and McKenna [27]).

Coastal erosion is defined briefly by the South Pacific Sea Level and Climate Monitoring Project as "the loss of land along the shoreline. It happens when sediment, in the form of sand and soil, is removed from the coast. Coastal erosion is a serious problem since it has a negative effect on the way of life, grouped settlements and economic activities of people who live near low-lying coastal land (UNEP [28]). Overall, we can conclude that the general causes of coastal erosion arise from both natural and human activities.

\subsection{Coastal erosion in Thailand}

Due to the long length of sea coast on the Gulf of Thailand (1,660 kilometers stretching along 17 provinces, including Bangkok) and the Andaman Sea (2,614 
kilometers), Thailand is confronted by a high risk of land erosion along the coasts. The high erosion rates, at an average of five meters annually, have been measured across 180.9 kilometers in 12 provinces or 10.9 percent of the Gulf of Thailand's coastal length (Maneerat [29]) as well as across five out of six provinces along the Andaman coastline for 90.5 kilometers out of 954 kilometers or 9.5 percent (Maneerat [29], Suvanich [30]).

\subsection{Areas affected by sea level rises}

A hypothetical situation where an incremental rise in the sea level in Thailand was simulated at zero, five, and 10 meters is shown in fig. 5(a)-(c), taken at the Jet Propulsion Laboratory, California Institute of Technology [31] and the details can be explained below.

At a five-meter rise in sea level, the simulation showed that some provinces in the central part of Thailand (Bangkok, Nonthaburi, Samutprakarn and Pathumthani provinces) and some areas on the Gulf of Thailand (the upper part of the Southern peninsula, mainly in Prachuabkirikhan, Chumporn, Nakorn sithammarat and Songkhla provinces) would be immersed. This would have a similar effect on the Southern part of Myanmar (Rangoon), the Southern part of Cambodia and also Hochiminh city in Vietnam.

As a result of a sea level rise of 10 meters, larger areas of the central region, i.e. the whole province of Samutsakorn and Samutsongkram, and some areas of Ayuthaya and Aungthong, would be submerged. More of the Eastern part of the Gulf of Thailand would be affected by this sea level rise (i.e. the Eastern part of Petchburi, extending south to Surathani and Samui Island). Its effects would extend to the Andaman Coast as well, especially some areas on the western coast of Malaysia, Central and Southern parts of Myanmar and Cambodia. This simulation predicts that Phanom Penh city would disappear; nevertheless, this level of sea rise would have no effect on landlocked Lao PDR.

\subsection{Measures to mitigate and protect against coastal erosion}

Rattanamanee et al. [32] revealed that the major causes of coastal erosion in Thailand emerge from both natural processes and human activities. Natural processes, including numerous incidents such as rising sea levels, shrinking residential areas, changing of the balance of shoreline sediment and climate change are considered crucial issues. It is also important to note that several human activities such as extracting sand from beaches, mining coral, removing mangroves, dredging channels, and constructing structures such as seawalls, groins and causeways can tremendously alter tidal circulation and wave processes around islands. Eroded land affecting public and private properties can be documented, the total extent of the damages - which includes the negative impact on the balance of coastal ecology and biodiversity, on coastal communities' quality of life, and on the country's gross economy - is difficult to evaluate.

The subsequent recommendations are suggested for the on-going mitigation and prevention of coastal erosion: First, relevant government agencies should 
establish a comprehensive policy or strategy roadmap to actively promote the prevention and remediation of damaged coastlines. This plan should allow all stakeholders the opportunity to participate in the decision-making at every stage in the process. Secondly, the most appropriate technical interventions should be chosen for each of the coastal areas based on the needs and conditions. For example, as a short-term solution, it is essential to construct seawalls, breakwaters and sand sausages to hold back waves from attacking the coast, carry outbeach and dune nourishment and artificial coral reef barrier construction to reduce tidal power before it strikes the coast.

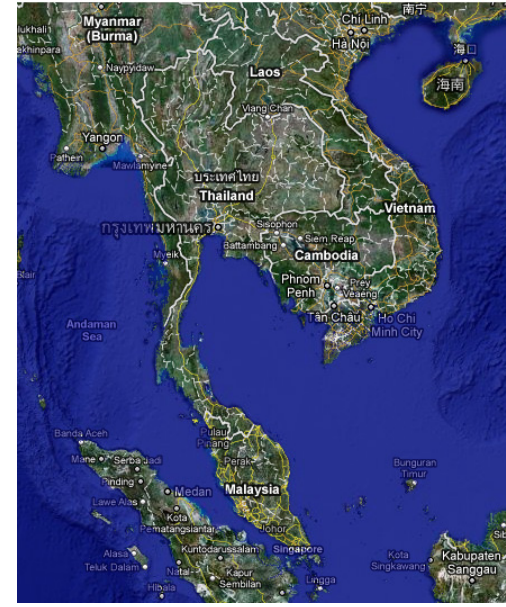

(a)

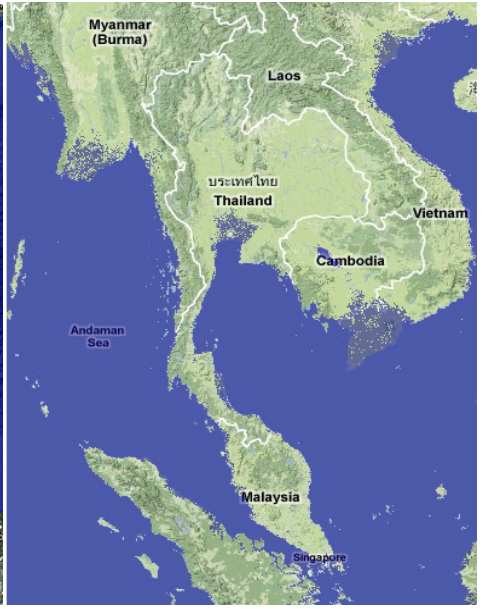

(b)

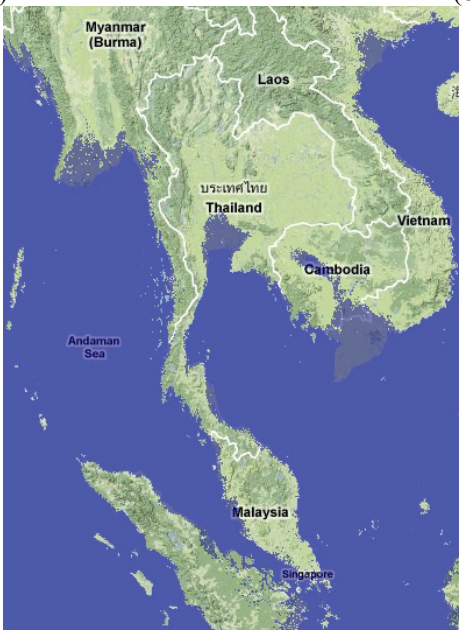

(c)

Figure 5: (a) Sea level rise $+0 \mathrm{~m}$. (b) Sea level rise $+5 \mathrm{~m}$. (c) Sea level rise +10 m. (Source: Jet Propulsion Laboratory, California Institute of Technology (2011). Accessed from www.flood.firetree.net/?11= $10.5310,99.0967 \& \mathrm{z}=12 \& \mathrm{~m}=14 \& \mathrm{t}=3$ 
In addition, results provided by Thampanya, et al. [33] indicate that mangroves could reduce the mean erosion rate from $3.3 \pm 0.4 \mathrm{~m} \mathrm{y}^{-1}$ to $2.3 \pm$ $0.4 \mathrm{~m} \mathrm{y}^{-1}$ as for the coastal segment without mangroves. As a long term solution, the natural environmental features of the area should be re-established, especially mangrove reforestation. In the case of severely eroded shorelines, Jarupongsakul [34] and Jarungrattanapong and Manasboonphempool [35] have proposed that it is necessary to launch measures by combining both short and long term solutions against the threat from sea level rises in order to preserve a sound environment for the benefit of future generations.

\section{Conclusion}

To mitigate against environmental disasters, the hydrological models have been applied to simulate river or stream flow and calculate water quality parameters. In Thailand, the hydrodynamic models, MIKE 11 and URSB, are considered appropriate models for flood forecasting and management.

This paper has established that flooding has been more frequent and violent in the last decade. Human activities are playing a key role in increasing the number and severity of natural disasters, especially through the reduction of rainforest areas and substitution by rubber and palm oil plantations, road construction and waterway diversion.

In addition, coastal erosion in Thailand is found on both the Gulf of Thailand and the Andaman Sea coasts. The Geographic Information System software simulation of sea level rises provided by California Institute of Technology shows that some areas of Thailand, especially in the Central and Southern regions would be immersed in the event of higher sea levels of more than five meters occurring. In the case of sea levels rising by 10 meters, the cities of Bangkok, Rangoon, Hochiminh and Phnom Penh would vanish from the map.

To effectively deal with the natural disasters of flooding and coastal erosion, all interested parties from private, government and non-government sectors should cooperate on setting short and long term plans, and their action plans by adjusting them to appropriately serve specific areas.

Proactive measures (city plan zoning, mangrove reforestation) and reactive measures (warning system installation and evacuation plans) should be set up to reduce the impact and minimize the loss of life and damage to property.

In conclusion, natural disasters will still occur and are difficult to avoid. However, resolutions of these disasters are to have good preparation and management including avoiding over-exploiting the natural resources.

\section{References}

[1] Natural Disasters in Thailand, Thai Meteorological Department (TMD), www.tmd.go.th/info/info.php?FileID $=70$

[2] McDonald, R., Introduction to Natural and Man-made Disasters and their Effects on Buildings, Architectural Press, Oxford, UK, pp.1-17, 2003. 
[3] Chankaew, K., Environmental Science, (8th eds), Kasetsart University Press, Bangkok, pp.22-23, 2008 (in Thai).

[4] Miller, G.T. Jr., Community ecology: structure, species interactions, succession, and sustainability (chapter 7). Environmental Science, 10th edn., Thomson Learning, Inc., pp.140-159, 2004.

[5] Bates, B.C., Kundzewicz, Z.W., Wu S. \& Palutikof, J.P., Executive summary. Climate Change and Water, Technical Paper of the Intergovernmental Panel on Climate Change, IPCC Secretariat, Geneva, pp.1-4, 2008.

[6] Nirapai Center, Flooding Situation, 2010. www.disaster.go.th/dpm/flood53/ flood53.html

[7] The International Disaster Database, Centre for Research on the Epidemiology of Disasters (CRED), www.emdat.be/result-country-profile

[8] Jarungrattanapong, R. \& Manasboonphempool, A., Adaptation strategies for coastal erosion/flooding: a case studies of two communities in Bang Khun Thian District, Bangkok., TDRI Quarterly Review, pp.11-18, March, 2008.

[9] Pilon, P.J. (eds), Guidelines for Reducing Flooded Losses, United Nations, International Strategy for Disaster Reduction (UNISDR), pp.3-4, 2002.

[10] Thai Meteorological Department-TMD, Natural Disasters in Thailand, www. tmd.go.th/info/info.php?FileID $=70$

[11] United Nations Educational, Scientific and Cultural Organization- UNESCO, Case studies: Moving towards and integrated approach (Chapter 14). Water: A shared responsibility, United Nations World Water Development, Report 2, pp.41-42, 2006.

[12] Nicholls, R.J., Analysis of global impacts of sea-level rise: a case study of flooding. Physics and Chemistry of the Earth, Parts A/B/C, 27 (32-34), pp.1455-1466, 2002.

[13] Nicholls, R.J. \& Mimura, N., Regional issues raised by sea-level rise and their policy implications. Climate Research. Vol.11, pp. 5-18, 1998.

[14] Costello, A. et al., Managing the health effects of climate change. The Lancet Commission. Vol. 373, pp.1693-1733, 2009.

[15] Kozka, Z. \& Holko, L., Analysis of rainfall-runoff events in the mountain catchment. Proc. of ERB and Northern European FRIEND Project 5 Conference, Demänovská dolina, Slovakia, 2002.

[16] Booij, M.J., Impact of climate change on river flooding assessed with different spatial model resolutions. Journal of Hydrology, 303 (1-4), pp.176-198, 2005.

[17] Mekong River Commission (MRC), Overview of the hydrology of the Mekong Basin, ISSN: 1728: 3248. November, 2005.

[18] Malone, T. et al., Development of improved hydrological forecasting models for the lower Mekong basin. Proc. Of the $5^{\text {th }} A M F F$ - Improving Inputs Towards Medium Term Flood Forecasting and Warning in the Mekong Basin, pp.125-131, 2007.

[19] Carroll, D.G., URBS (Unified River Basin Simulator): A rainfall runoff routing model for flood forecasting \& design version 4.30, manual, 2007. 
[20] Skotner, C., Klinting, A. \& Ammentorp, H. C., MIKE Flood WatchManaging Real-Time Forecasting, DHI Water \& Environment, Denmark, 2005.

[21] Narrabri Shire Council, Final Report. Narrabi flood study review, Prepared by URC, pp. 11-15, 2009.

[22] Chitprom, P. \& Patsinghasaneel, S., Application of hydrodynamic model for flood forecasting in Chao Phraya River Basin for year of 2008, Water Crisis Prevention Center, Department of Water Resources, Thailand, Proc. of 7th Prince of Songkhla University Eng. Conference, 21-22 May, 2009.

[23] Taesombat, W. et al., Flood Mitigation Study in Nam Loei River Basin Using River Basin, Modeling. Proc. of the $3^{\text {rd }}$ National Convention on Water Resources Engineering, pp.1-10, 2009.

[24] Wannasiri, S., Rubber Tree, 3rd edn. Than Kasettakam Press: Bangkok, 1999.

[25] Land Development Department (LDD), Rubber Tree: Technical paper, Office Research and Development of Land Management, Thailand. pp. 11-12, 2005. www.ldd.go.th/Lddwebsite/web_ord/Technical/ pdf/P Technical06020.pdf

[26] South, G. R., Ocean and coastal issues and policy responses in the Pacific islands, Oceans and Coasts at Rio +10 Assessing Progress, Addressing Continuing, and New Challenges, UNESCP, Paris, December 3-7, 2001.

[27] Cooper, J.A.G. \& McKenna, J., The temporal and spatial dimensions, Social justice in coastal erosion management. Geoforum, 39(1), pp.294306, 2008.

[28] UNEP, How will global warming affect my world?, Information Unit for Convention, International Environment House. Switzerland, 2003.

[29] Maneerat, S., Coastal Erosion in Thailand. Database of marine resources and coastal, Department of Mineral Resources, Ministry of Natural Resources and Environment, Thailand, 2011 www.km.dmcr.go.th/ index. php?option $=$ com_docman\&task $=$ cat_view\&gid $=124 \&$ Itemid $=36$.

[30] Suvanich, P., Geohazard, Knowledge and management, Kampeewan Press: Nonthaburi, 2009.

[31] Jet Propulsion Laboratory, California Institute of Technology, www.flood.firetree.net $/$ ?l $=10.5310,99.0967 \& z=12 \& \mathrm{~m}=14 \& \mathrm{t}=3$

[32] Rattanamanee, P. et al., Integrated knowledge of shore protection projects, Proc. of the $6^{\text {th }}$ Prince of Songkla University Engineering Conference, 8-9 May, 2008.

[33] Thampanya, U. et al., Coastal erosion and mangrove progradation of the Southern Thailand, Journal of Estuarine, Coastal and Shelf Science, pp. 68, 75-85, 2006.

[34] Jarupongsakul, T., A future sea-level rise: its impacts on the coastal erosion in the upper Gulf of Thailand, The Sunday Bangkok Post, May 21, 2006.

[35] Jarungrattanapong, R. \& Manasboonphempool, A., Adaptation strategies for coastal/erosion/flooding: A case study of two communities in Bang Khun Thain District, Bangkok, TDRI Quarterly Review, 23(1), pp.11-18, 2008. 